\title{
Beyond the seas
}

\author{
By Stephen Dixon
}

Stephen Dixon studied Fine Art at the University of Newcastle-upon-Tyne, and Ceramics at the Royal College of Art, graduating in 1986. His work features in numerous public and private collections, including the Museum of Arts \& Design, New York, the British Council, the Crafts Council, the Victoria and Albert Museum, the Royal Museum of Scotland, and the Fine Arts Museum of San Francisco. He is currently employed as Professorial Research Fellow in Contemporary Crafts at MMU Cheshire, investigating the contemporary printed image in ceramics. Specific research interests include the British satirical tradition (in both printmaking and ceramics), commemorative wares and 'pop' culture, and the development of sociopolitical narratives in contemporary ceramics.

Abstract: This paper describes a practice-led research project undertaken in Australia in 2006, in which I sought to explore the relationship between radical changes in cultural/geographical environment and the production of unique forms of material culture. In this case the shift in environment was brought about by migration (enforced or otherwise) from the UK to colonial Australia, and the crafted artefacts of the colonial period (and after) were taken as representative of a particularly Australian material culture. As a maker it was important to me that this research was developed primarily through practice, supported by museum/archive study and fieldwork in Australia. The project therefore proposed a range of historical Australian artefacts as the subject of study, and my own creative practice as the vehicle of study.

In section 1 (fieldwork), I describe the initial boundaries of the project, list the research questions, and consider the project's location and its context within the wider objectives of the Here and There (HAT) project. Specific artefacts and objects are identified and described, as representative of a unique material culture. Section 2 (reflective practice) considers some of the ethical issues encountered and describes the evolution of my research focus during the early stages of the project, particularly the discovery of depression era 'making-do' artefacts, and a growing interest in Australian folk narratives and 'icons' of popular culture. It then describes the development of a series of works made in response to the initial Australian fieldwork over the following two years of studio practice in the UK. Section 3 (conclusion) reflects upon the outcomes of the study - in particular the practical and conceptual changes undertaken inmy creative practice as a result of the project - and lists the exhibitions, conferences and articles through which the 'Beyond the Seas' project has since been disseminated. 


\section{Section 1. Fieldwork}

Beyond the Seas was a practice-led research project in which I explored the ways in which cultural and geographical dislocation influences craft practice and the creation of material culture. This question was investigated through the medium of my own creative practice, informed by research on location in Australia. The crafted artefacts produced by early colonial settlers and their descendants, and also those of Indigenous Australian makers were the main subject of my study. I was interested in exploring the 'hidden' narratives and knowledge embodied in these objects, the ways in which life experiences can be infused into an object through the hand (and mind) of its maker. It was therefore important that the research was developed primarily through practice, supported by periods of museum and archive study and research on location in Aboriginal communities in the Pitjanjatjara lands. The intention behind my own (albeit temporary) relocation was to gain an insight into the more profound instances of dislocation experienced by colonial period transportees and settlers.

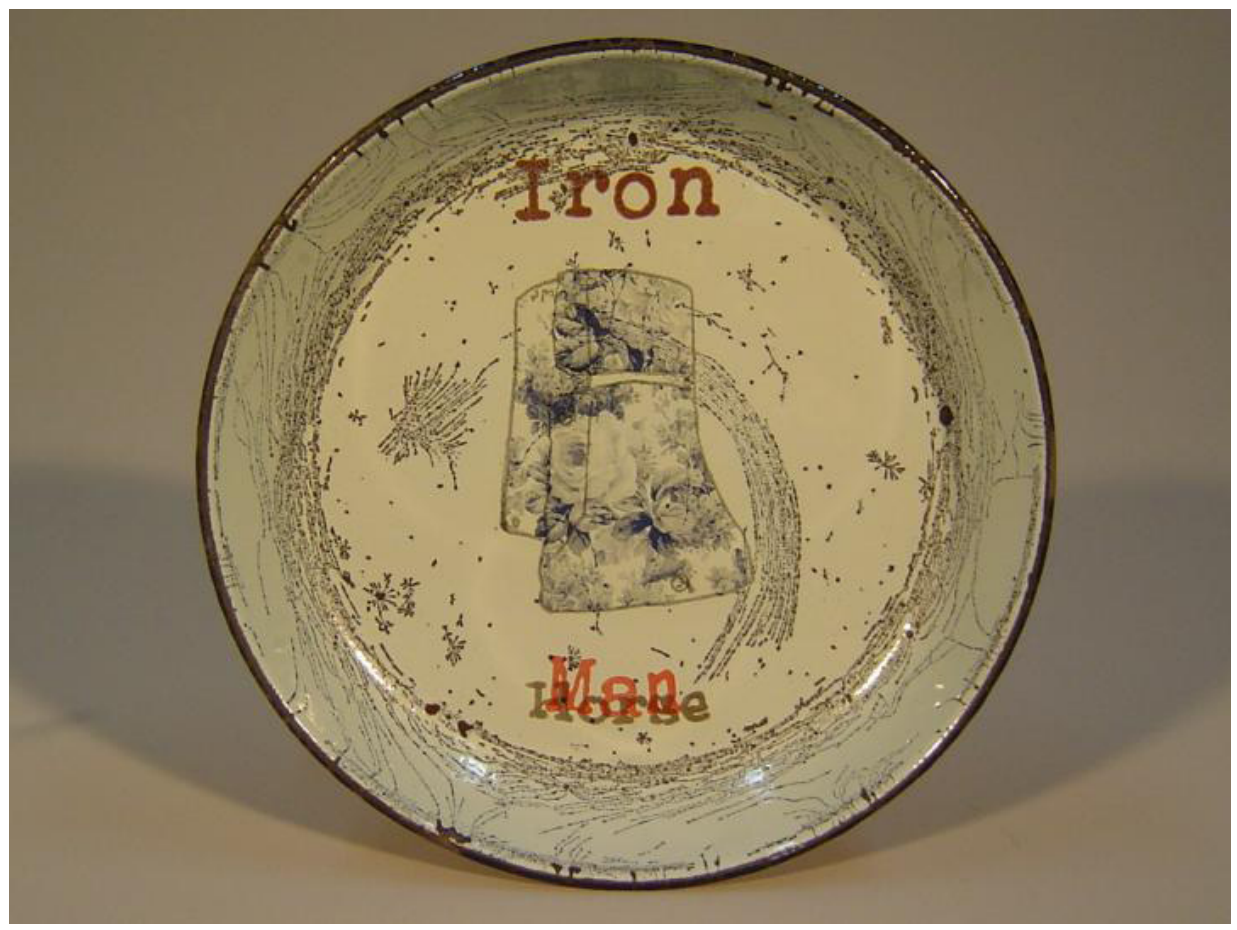

Fig. 1: An example of re-located practice, Iron man, (enamelled tin plate).

Found and re-worked on location in Adelaide, Australia, March 2006. 


\section{Context and Location}

The Beyond the Seas project was co-funded by the Arts Council UK and the Arts and Humanities Research Council, and was developed within the context of the Here and There (HAT) international research exchange project. The HAT Project was a programme of International Fellowships for the Contemporary Crafts, which created opportunities for critically engaged and established designermakers to undertake practice-based research in a range of international contexts. Over a period of two years from 2006 to 2008 the programme of thematically linked fellowships built a network of artists and hosts, collectively exploring practice-led research, documentation, exchange, dialogue, collective evaluation, and critical writing. ${ }^{1}$

My project hosts were the Jam Factory Craft and Design workshops in Adelaide, South Australia, where I was based from January to April 2006. I was given open access to a wide range of technical studios and facilities, and was welcomed into the wider creative community of Adelaide.

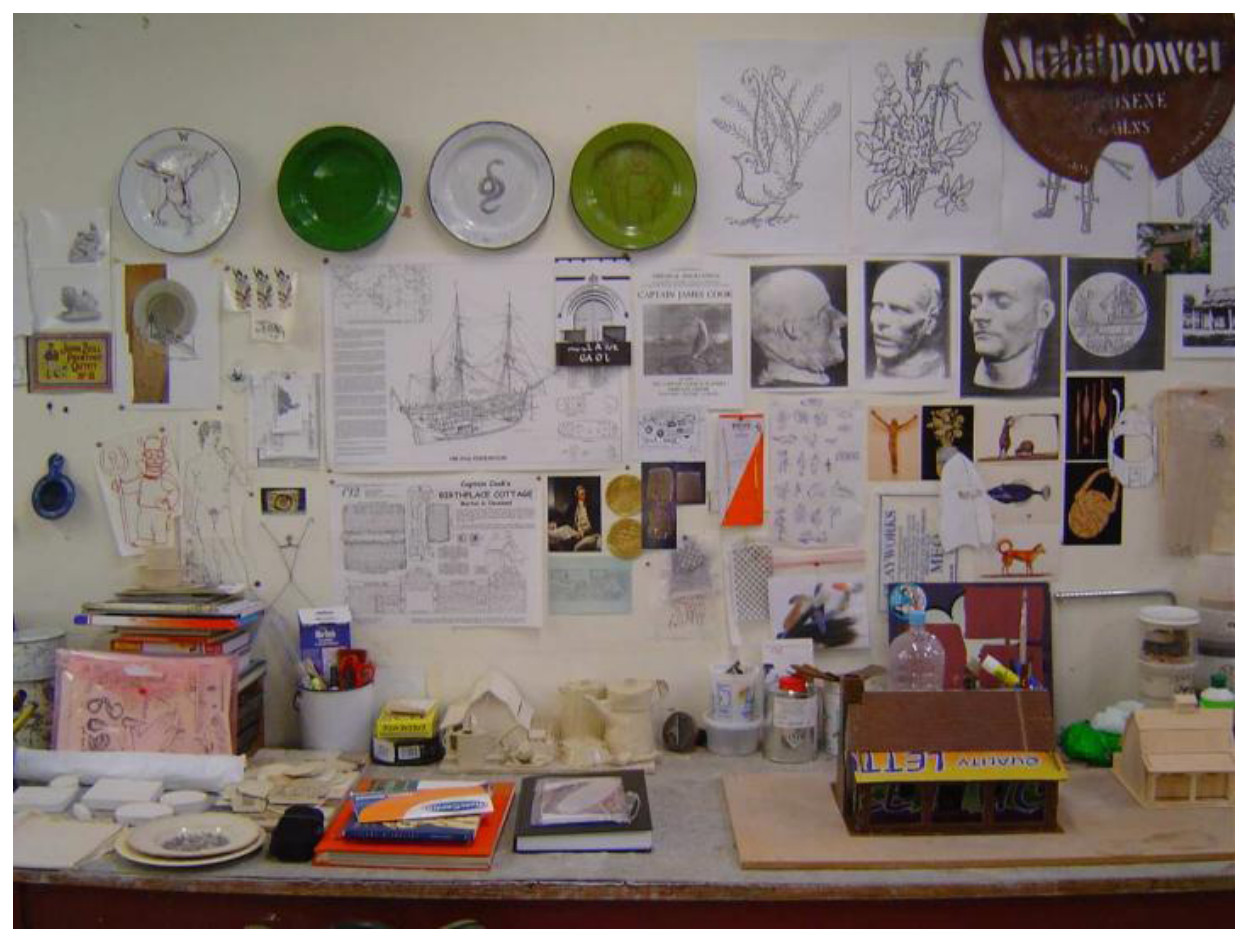

Fig. 2: Work in progress, Jam Factory studio, March 2006.

1 The HAT project is available at http://www.hat.mmu.ac.uk/ 
The Jam Factory additionally facilitated a research trip into the Pitjantjatjara Aboriginal lands in the Musgrave Ranges on the northern edge of South Australia. A permit is required to legally enter these homelands, and a guide with local knowledge is recommended. I was fortunate in being able to travel with Colin Koch, then Director of Ku Arts, on one of his regular support trips to the Aboriginal Arts Centres at Ernabella, Tjungu Palya, Freegon and Indulkana. I also had the opportunity to travel to Sydney, Melbourne and Canberra to visit important museums, archives and collections.

Australia, the subject and location of this research project is a contested territory, as can be seen in the different approaches to its mapping. A map taken from the perspective of a British geographical text-book of 1919, asserts Imperial 'ownership' of Australia through its depiction in British Empire pink.

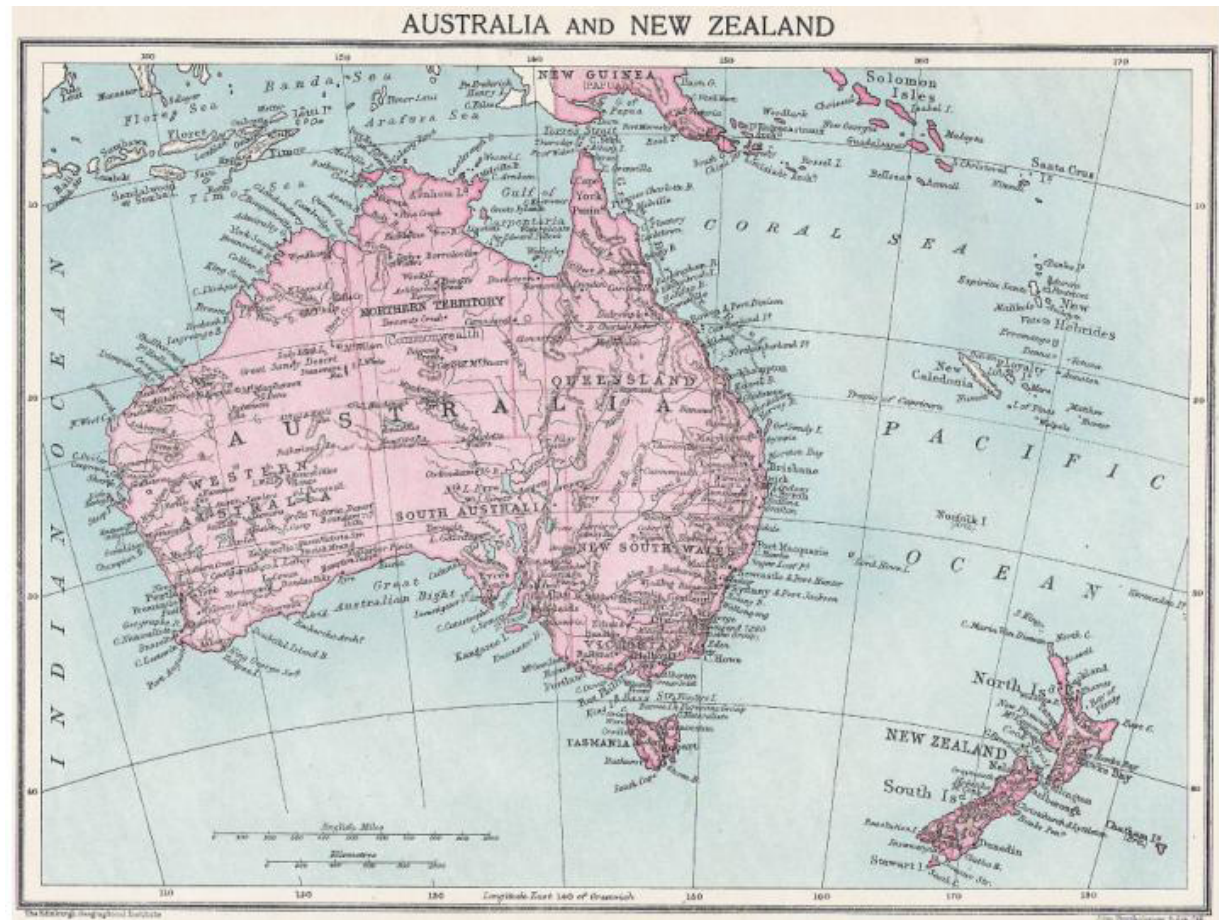

Fig. 3: Map of Australia and New Zealand, from a British geographical text-book of 1919.

This anachronistic view of Australia has of course been challenged in a number of ways. For example, another map 'Tribal Boundaries in Aboriginal Australia', compiled by the Australian anthropologist Norman B. Tindale (1974), gave a detailed breakdown of the Australian continent into tribal regions and territories, with clearly defined tribal boundaries. This map provided an academic repudiation of the colonial view of indigenous Australians as nomadic wanderers, and was influential in the movement towards Native Title begun by the Aboriginal Land Rights (Northern Territories) Act of 1976 and continued by 
the Mabo Case of 1992. Another view of a more ancient land occupation and ownership is asserted by a contemporary indigenous painting of Australia, a detail from a world map, painted in 2006 by Peter Nyaningu, a tribal elder of the Ernabella community. Though the cartographic representation of Australia follows a western model, the painting technique references a more 'authentic' identity. The Pitjantjatjara Aboriginal homelands occupy the square black area in the centre.

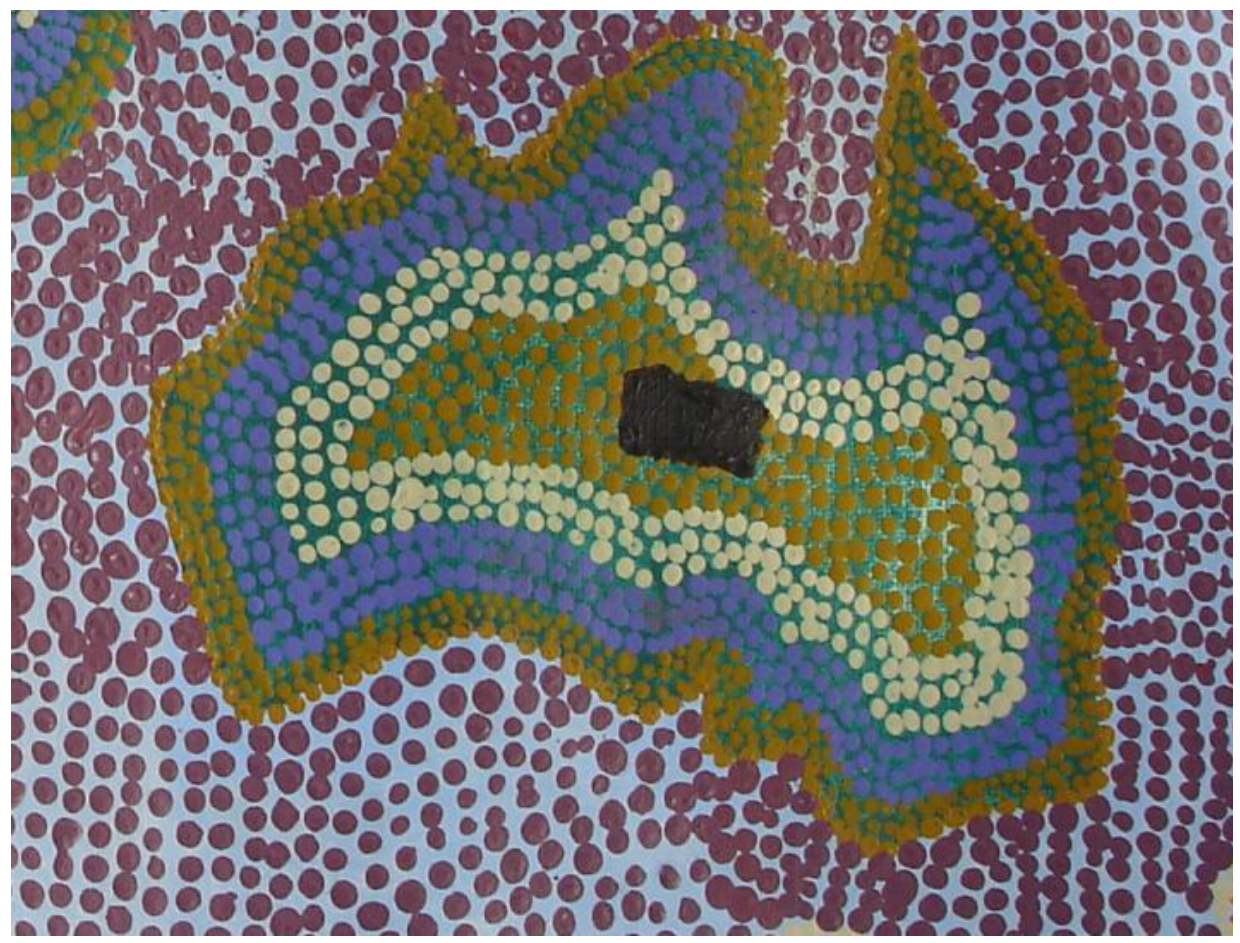

Fig. 4: Detail from a map of the world (2006), painted by Indigenous artist Peter Nyaningu.

\section{Research Questions}

At the outset I was interested in the material culture and crafted objects of settlers in Australia who came from Britain. What did the artefacts made and used by these British settlers reveal about the effects on them of emigration? For example, did these colonial artefacts differ from artefacts produced in the UK? Were new forms of artefact created, and if so why? I began with a broad subject review (or rather, 'object' review) in museums, libraries and archives in Adelaide, Melbourne, Sydney and Canberra ${ }^{2}$ and discovered a number of answers to these questions. This survey led to the expansion of the chronological remit

2 The most influential of these were the Powerhouse Museum, Sydney, the National Gallery of Australia, Canberra, and the Aboriginal Cultures Gallery at the South Australia Museum, Adelaide. 
of my research beyond theimmediate settler period, to include artefacts made by later generations of Australian makers. The survey revealed some uniquely Australian artefacts; convict love tokens and tattoos, bush toys and furniture, utility quilts and domestic textiles, many of these produced as a direct result of their makers' experiences of cultural and geographical dislocation. These objects are characteristic of an evolving 'making-do' vernacular tradition, influenced by economic hardship, a harsh and unforgiving environment, and a scarcity of resources and familiar materials.

\section{Artefacts}

It will be useful at this point to examine and describe some examples of these 'dislocated' objects, bearing in mind their stylistic and chronological diversity. I should also point out that some of the illustrations in this section are based on the original source objects/images, but have been 'mediated' through inclusion in my own practice.

Convict love tokens were made by de-facing and re-engraving George III cartwheel pennies. They were produced throughout the majority of the transportation period ${ }^{3}$ by British convicts awaiting transportation to Australia, and sometimes made for the convicts by professional engravers who plied their trade on the prison hulks moored in the Thames. The tokens were made in anticipation of the convicts' separation and dislocation, and given as keepsakes to the loved ones they were unlikely ever to see again. Although most remained in the UK, they have been described as 'the first truly Australian artwork' (Schofield and Fahy, 1990). Sometimes crudely drawn and often misspelled, the love tokens both embody and evoke the personal tragedies and hardships faced by the convicts. Their messages are often both personal and poignant (Field and Millett, 1998). One typical token carries the inscription:

Accept this dear mother from your unfortunate son. Thos. Alsop.

Transported July 25th Aged 21, 1833.

On the reverse is the rhyme:

The rose soon drupes and dies, The brier fades away,

but my fond heart for you I love,

shall never go astray.

3 Convicts were transported to Australia from 1787 to 1868, love tokens have been dated from 1780 - when convicts were imprisoned in de-commissioned warships moored in the Thames prior to their transportation - to 1856. 


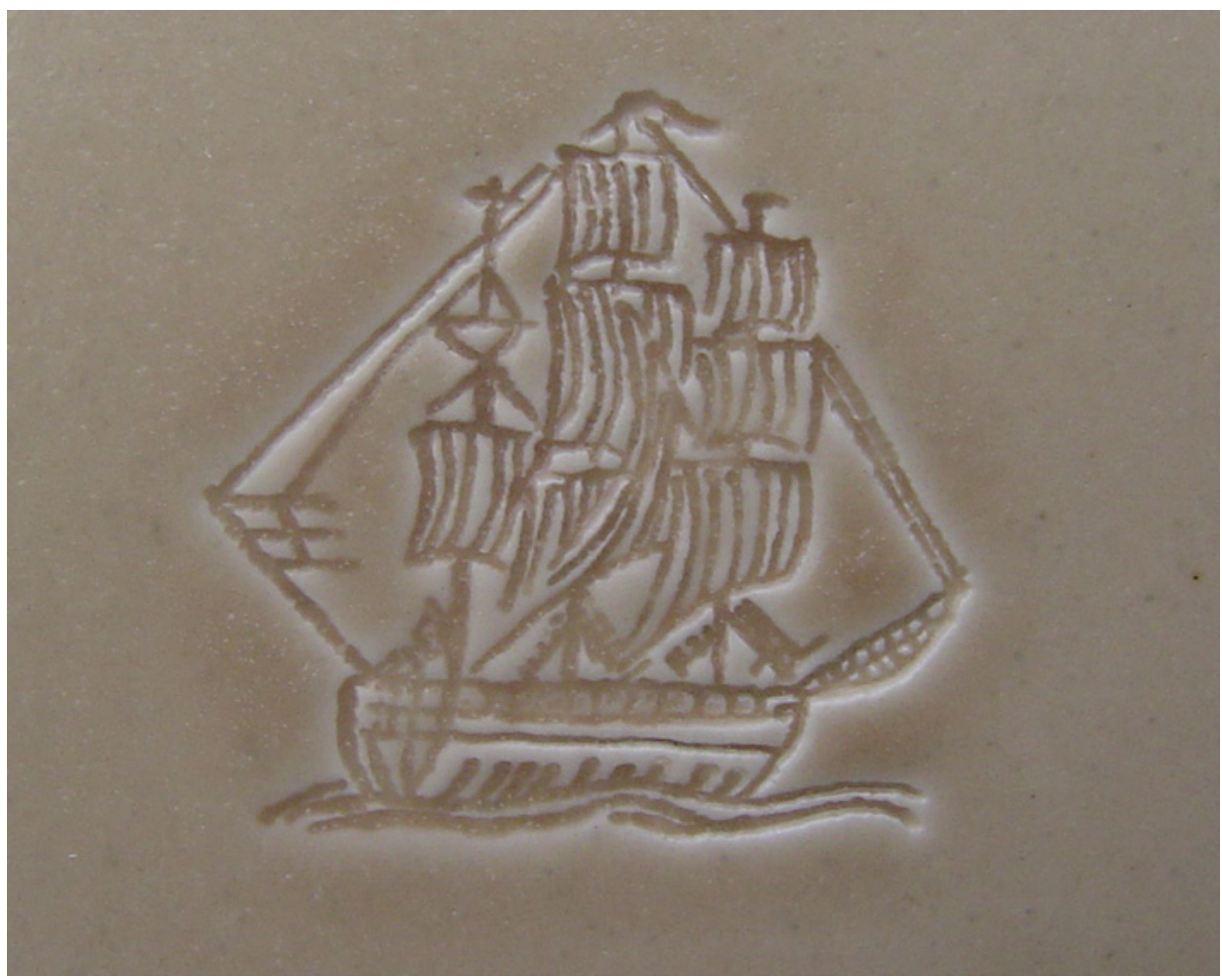

Fig. 5: Detail of 'Cargo 2'. Image of a convict transport ship, from a convict love token.

Additional evidence of the troubled state of mind of these transportees might be seen in the iconography of convict tattoos, which often depict 'Faith' (a crucifix), 'Hope' (female figure with anchor) and 'Charity' (female figure with small children) and the names of husbands, wives and loved ones. The craft of tattooing using soot from oil-lamps as pigment was a common practice both on the prison hulks and during the long sea voyage to Australia, and was a primary means of identifying convicts for the colonial authorities. Many of these images (such as those in the convict dissection samples held in Guys Hospital Museum, London.) are typical of the iconography of contemporary material culture, and can also be seen in the popular prints, ceramic wares and engraved glassware of the period. However, the dating of recorded tattoos shows that at least $40 \%$ of convicts were tattooed while awaiting sentence or during transportation. Documented images of handcuffs, the symbol of the prisoners' broad arrow, kangaroos, snakes and references to 'the land of sorrow', would tend to support these statistics (Maxwell-Stewart and Bradley, 1998). 


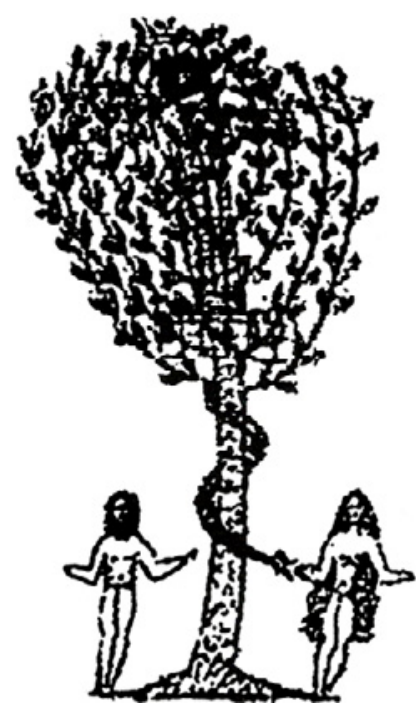

Fig. 6: Adam and Eve, image taken from a convict tattoo.

Quilted textiles were another type of artefact produced during the voyages of transportation. The Quaker and prison reformer Elizabeth Fry, supported by the British Ladies Society for the Reform of Female Prisoners, supplied the convict women of Newgate Prison with the necessary fabrics and sewing materials to produce patchworks during their journey, to be sold on arrival in Australia. Each woman was given 2 pounds of patchwork pieces, 9 balls of sewing cotton, 24 hanks of coloured thread, 100 needles, pins, tape, bodkin, thimble and scissors. The Rajah Quilt, made by several unidentified women on the transport ship 'Rajah' bound for Van Diemens Land in 1841, and now in the National Gallery of Australia, Canberra, is the only known surviving example. Though the circumstances of its making are exceptional, the form and techniques of the Rajah Quilt are typical of English patchwork textiles of the period. A more original Australian textile form, known as the Wagga or bush rug, was developed later, during the depression era of the early 20th century, when 'making-do' became an economic necessity. The Wagga was a type of utility quilt, and was made by sewing patches of recycled fabrics (often from menswear suiting pattern books) to a coarse jute or cotton backing of flour sacking. Waggas were often made by men (typically farmers and shearers) and the direct and crude methods of construction reflect the rigours of rural Australian life.

Similar recycling principles were broadly applied in a domestic context. This widespread practice of 'making-do' was officially advocated in the 'how-to' booklet Makeshifts, produced by the New Settlers League of Victoria in 1923. Organisations such as the New Settlers League were set up to assist new settlers, particularly agricultural workers 'to accommodate themselves to new circumstances' (Jupp, 2001: 312). Makeshifts offered practical guidance on the manufacture of furniture and kitchen utensils using packing cases, kerosene cans and oil drums as raw material. (Interestingly, Makeshifts was sponsored 
by kerosene manufacturer British Imperial Oil). The booklet was so popular in depression-era Australia that an enlarged edition was re-published the following year.

This makeshift flair, practicality and eccentricity can be seen in the extensive McAlpine collection of Bush Furniture in the Powerhouse Museum, Sydney. Typical of this is a food safe or bush pantry made in Queensland c1925, from a disused oil barrel (Object ref. 92/305). "It appears that the maker was inspired by the 'Rotary Kitchen Canister' advertised in Anthony Hordern's 1923 mail order catalogue, and went to elaborate lengths to create a home-made replica. The skill needed suggests that the maker's normal farm work may have involved using sheet metal to make rudimentary water tanks and roofing. A fine example of 'making-do', involving the salvaging of a commonplace refuse item and transforming it into a useful piece of furniture..." 4

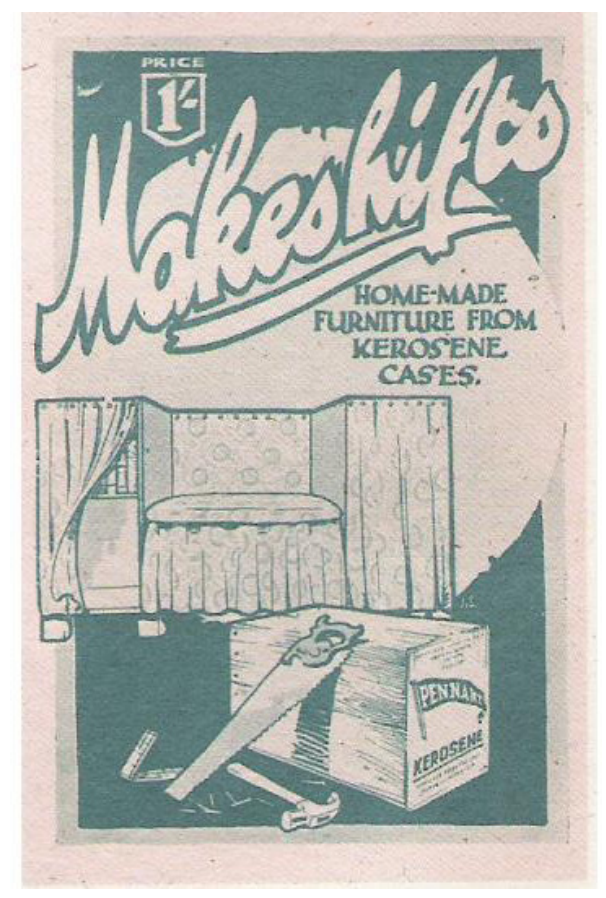

Fig. 7: 'Makeshifts' instruction booklet, Published by the New Settlers league of Victoria, 1923.

In addition to colonial and settlers' artefacts, I was also searching for historical objects which told something of the relationship between settlers and indigenous Australians.

Although Captain Cook noted in his journal that very few western artefacts were of interest to aboriginals at first contact "unacquainted... with...the necessary

4 From the 'statement of significance', Object 92/305, Powerhouse Museum Collection online archive notes. Available at http://www.powerhousemuseum.com/collection/database/ 
conveniences so much sought after in Europe, they are happy in not knowing the use of them as they seem'd to set no value upon any thing we gave them, nor would they ever part with anything of their own for any one article we could offer them."(Cook, J. in Hughes, R., 1987, p. 399) It is clear that Aboriginals were very interested in acquiring those European objects, artefacts and materials which they judged to have practical uses, fish hooks, knife blades and axe-heads for example. Indeed, instances of more culturally complex artefacts migrating across cultural borders do exist. One example of an artefact making this cultural crossover is the so- called King-Plate.

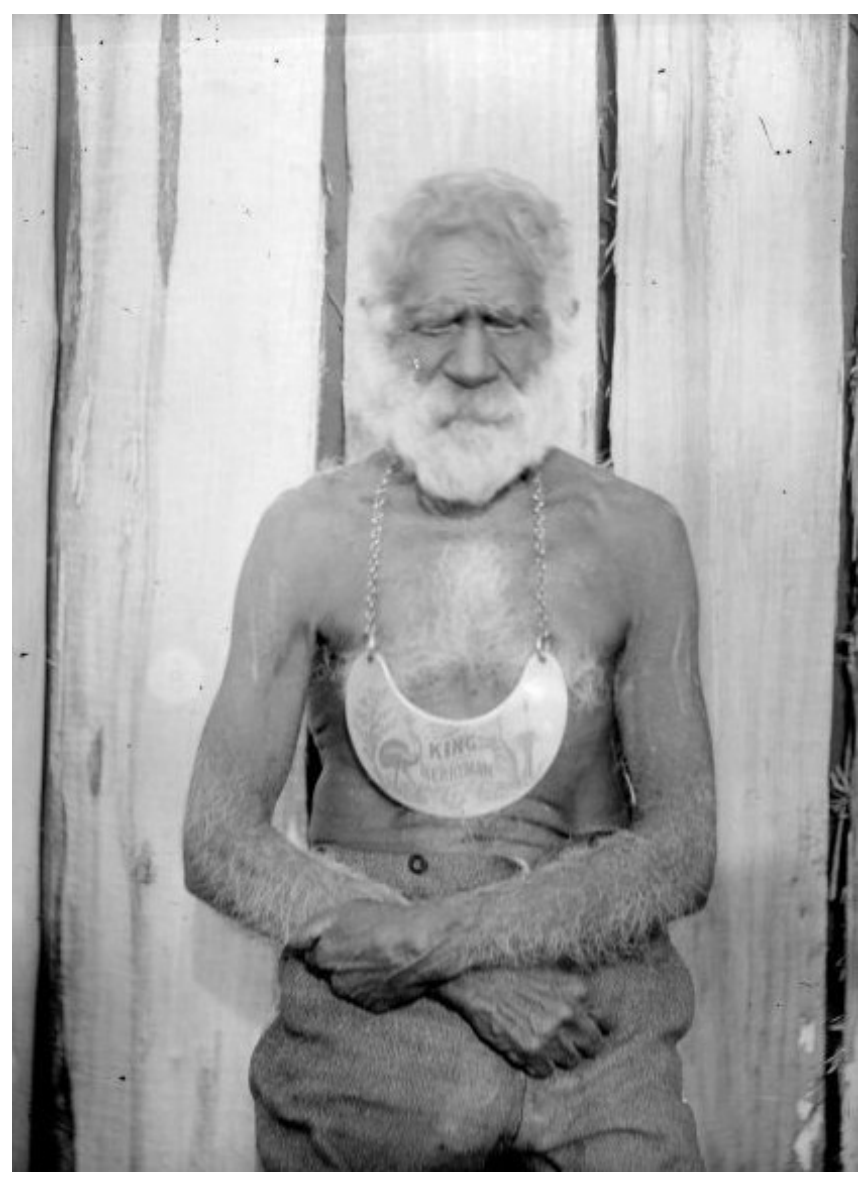

Fig. 8. Umbarra, known as King Merriman, with king plate.

Photographer William Henry Corkhill, c. 1900. National Library of Australia. 
These were copied from a regimental brass throat-plates or 'gorget' which identified military officers, and were prized as both a decorative artefact and an indicator of status within tribal groups (Troy, 1993). Their popularity amongst Indigenous Australians (and in parallel amongst Indigenous Americans in colonial America) was encouraged by the colonial authorities, and their adoption supported the imposition of European systems of social hierarchy in order to subvert traditional Indigenous social structures.

Kimberley Points provide a further example of artefact migration. In this instance, indigenous artefacts were adapted to exploit the availability of new materials. Stone spear points, flaked on two sides, were traditionally produced in the Kimberly Region of the Northern Territories. They were both practical and aesthetically prized, and were collected and traded throughout aboriginal Northern Australia. Glass provided a perfect alternative material, and though rare was known to Aboriginals before European colonisation through trade with Indonesian Trepang fishermen. (Trepang or sea cucumber was native to Australia, and was prized in Chinese medicines as an aphrodisiac.) Following European colonisation, discarded bottle glass, along with porcelain from dinnerware, became more readily available, and was adopted and recycled by Indigenous spear-makers. Colonial expansion and the construction of the overland telegraph line introduced another source of raw material, in the form of ceramic telegraph insulators. The combination of these new materials, together with an increased demand from non-indigenous collectors has arguably led to the transformation of Kimberley points from 'authentic' ethnographic objects to 'virtuoso tourist art' (Harrison,2006: 63-68).

Another type of Indigenous artefact to survive the transition from pre-colonial to post-colonial society is the bush toy. Traditionally, wood and bark discs featured in Aboriginal child's-play as a game of target practice to teach spear-throwing skills. Such objects have their contemporary counterpart in the push-along vehicles made by the Arrernte children of Central Australia. What has changed in recent times is the availability of 'new' materials. Traditional organic materials (wood, bark, sinew and resin) have given way to manufactured materials such as recycled tin and fencing wire, and traditional imagery (animals and birds) has been supplanted by motorcycles, trucks and helicopters. My travels to the Aboriginal art centres in the Pitjantjatjara lands led me to encounter the most iconic and ubiquitous of contemporary Indigenous artefacts, the dot-painting on canvas. 


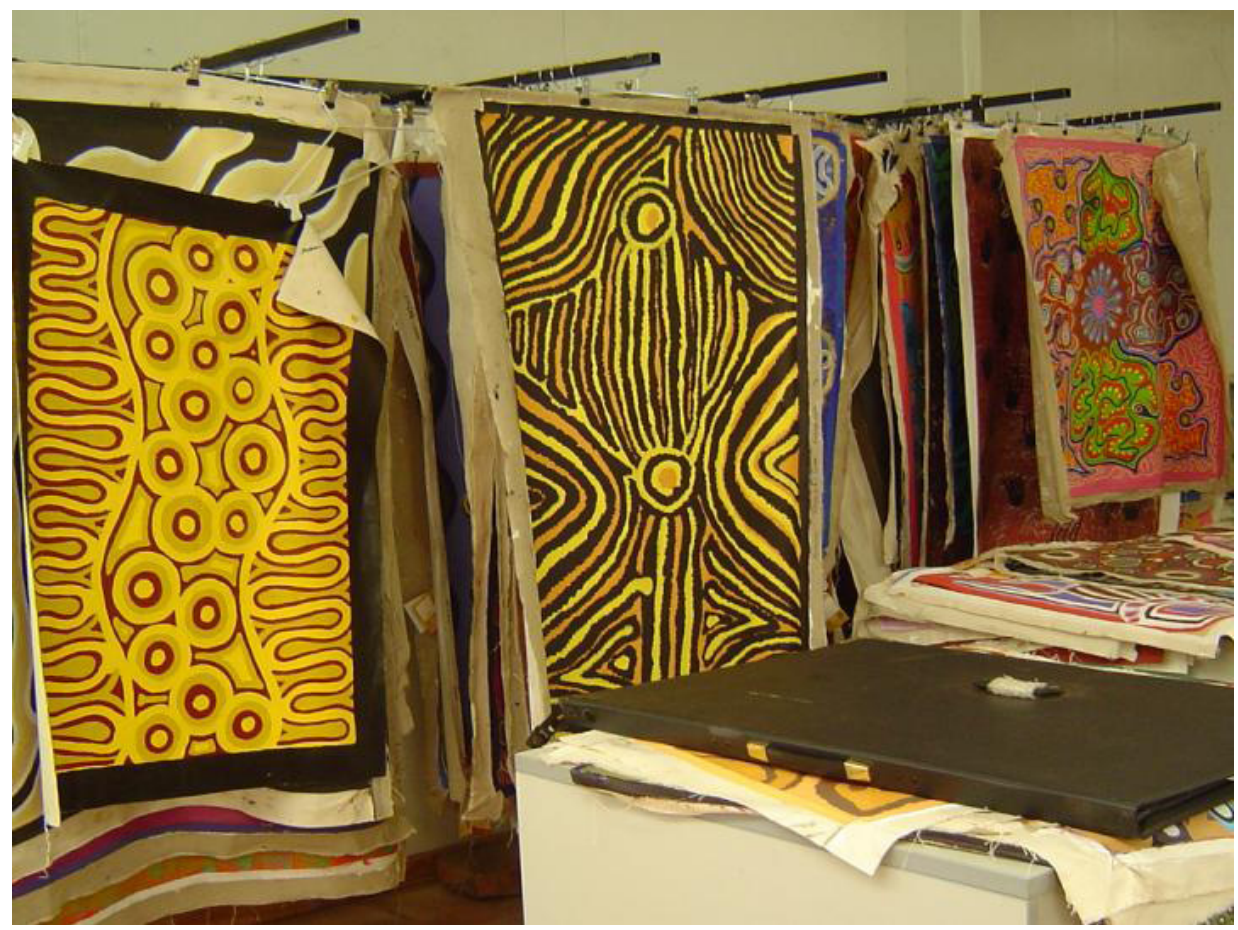

Fig. 9: Racked canvasses at Freegon Art Centre, awaiting transport to galleries in the coastal cities of Australia.

Muecke and Shoemaker (2004) have described how this art-form recently evolved: "For a long time Aboriginal plastic arts were tied to specific places, bodies and ceremonies and were not produced for sale or exhibition. In the 1970s, people were encouraged to produce paintings on bark or canvas, and a new chapter began in the history of Australian art, as an authentic and ancient set of images reasserted itself over the more ephemeral art forms of the settlers. Far from being fixed, these images were original and modern, yet continuously reaching back to the Dreaming cultures for inspiration."

Much debate has centred upon the 'authenticity' of this painting tradition, but authentic or not, the international commercial success of Australian Indigenous art is beyond question, and contributes an estimated 50 million US dollars per annum to the Australian economy (Muecke and Shoemaker, 2004).

In my visit to the Pitjantjatjara lands I saw at first hand how the Art Centres provide an invaluable service to the Aboriginal artistic communities: maintaining market networks, technical and social support structures, and promoting the long-term viability of Indigenous Australian arts.

Much of the acrylic-on-canvas painting has maintained a traditional orientation, informed by kinship-related dreaming and relationships with the land. However, a younger generation of Indigenous painters have begun to challenge this viewpoint, exploiting the formal traditions of Indigenous painting, whilst engaging 
with contemporary social and political issues. For example, Indigenous artist Gordon Bennett's works question 'settler' values, and are highly critical of a national identity forged in the absence of what he describes as 'The Australian Other'.

\section{Section 2: Reflective practice}

My early period of research had therefore identified a number of object types and individual artefacts, which had been 'defined' by their makers' experience of colonial dislocation and economic austerity. It also brought to light some important ethical issues, and revealed the potential for new avenues of research through practice.

\section{Ethical issues}

A number of ethical issues were raised, both by the initial preparations for the project, and by the experiences gained during the residency and in the field. These issues include cultural sensitivities around the imperial/colonial legacy, engagement with Aboriginal Protocols, and reflection on the context of my own 'political' craft practice. Consideration of these issues, some of which were not anticipated, informed both the context and direction of the project.

The pervasive legacy of the British Empire, its traditions, institutions and the monuments to its heroes, can be seen throughout Australia. Imperial monuments abound, in all of Australia's major cities. In particular, memories of colonial Australia's bleak beginnings are preserved in the edifices of crime and punishment. The prisons at Hyde Park Barracks and Darlinghurst, both built by convict hard labour, still survive the former as a museum of penal history, the latter more surprisingly as home to the National School of Art.

Old Melbourne Goal has now become a monument to the memory of the goldfields robbers and bushrangers of popular legend. The death masks of these criminals, cast in plaster after their execution, now decorate the prison cells, including that of Ned Kelly, executed there on 11 November 1880.

Several more artefacts illustrative of the brutality of the colonial penal system can be seen in the museum at Old Melbourne Gaol, most memorably for me the calico 'silence hood', designed to prevent recognition and communication between prisoners.

Cultural sensitivity was also a major ethical issue in the Aboriginal communities. I had hoped to document the work done at the Indigenous Art Centres while 'in the field', but quickly encountered Aboriginal protocols around the taking and ownership of images, which made photographic documentation of this stage of the project difficult. 
Protocols also (quite rightly) prevented the taking of anything from the homelands without specific permission. An example of dealing with this was the finding of a dessicated skeleton of a perentie (a monitor lizard) discovered in the Malilanya cave, a historical Aboriginal site near Ernabella. I was excited by this discovery, which unlocked a latent interest in the incorporation of animal bone into clay bodies (the principle of bone china). I began to plan a project, which proposed to incorporate local Aboriginal myths relating to the perentie, within a bonechina ceramic object made from the calcined bones of the lizard. The idea was that this lizard-bone china artefact would then be returned to the homelands. However, despite local permission to take the skeleton away, I wasn't convinced that this was acceptable within the terms of the protocols, and so the lizard was left where it was found in the Pitjanjatjara lands.

Nevertheless, the 'bone-china' idea had taken root, and as an alternative to perentie bones, the return trip to Adelaide was spent collecting bones from the plentiful road- kill along the edge of the main highway. (These were mostly bones from Kangaroo and Emu, co-incidentally the iconography of Australia's coat of arms.)

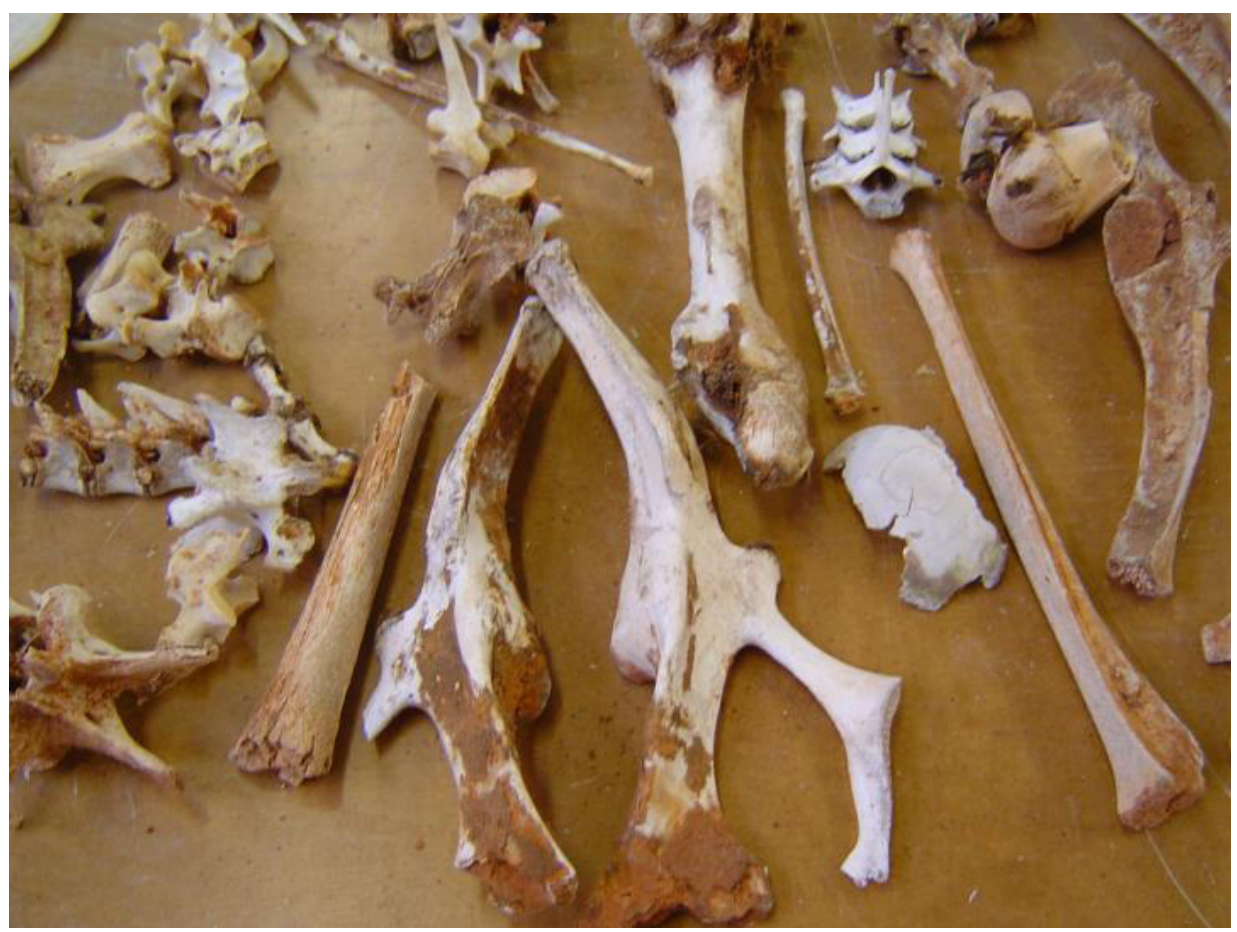

Fig. 10: Bones laid out for identification in the ceramic studio at the Jam Factory.

My collection of kangaroo and emu bones were turned into bone ash at the Jam Factory studio (by calcining in the kiln and grinding to a fine powder) and posted back to Manchester, for further development in the studio there. 


\section{Evolving research interests}

'Beyond the Seas' presented me with an interesting dilemma: how to operate as a 'politically-engaged' maker in a politically unfamiliar environment. Even after a short while in Australia I was aware of cultural and political issues, which, on my own territory, I would have readily engaged with. However, I did not feel comfortable in attempting this, as I felt that my knowledge of Australian history, culture and politics was superficial, at best that of an informed 'outsider'. To some extent I had anticipated this, and had chosen to examine issues indirectly, through their effects upon the making of artefacts, rather than attempting to tackle them head on. All of this resulted in a very different approach towards working in the studio at the Jam Factory, where I was keen to develop a more experimental approach to making and materials.

Perhaps inevitably then, the development of new attitudes to practice in residence and the consideration of ethical issues in the field resulted in some reshaping of my research interests within the project.

In addition to my initial interest in the development of colonial artefacts and the concept of making-do, I had become interested in the 'iconisation' of particular individuals, and in the narratives that have emerged around them. Predominant in this line of enquiry was the folk-hero Ned Kelly, whose death mask I had encountered at the Old Melbourne Gaol museum. The Ned Kelly story is the stuff of legend, born into a poor family of Irish immigrants, Kelly was apprenticed to a bushranger at the age of 14 , a life of petty crime then escalated into bank robbery and murder, and an epic man-hunt culminated in the famous shoot-out with police at Glenrowan.

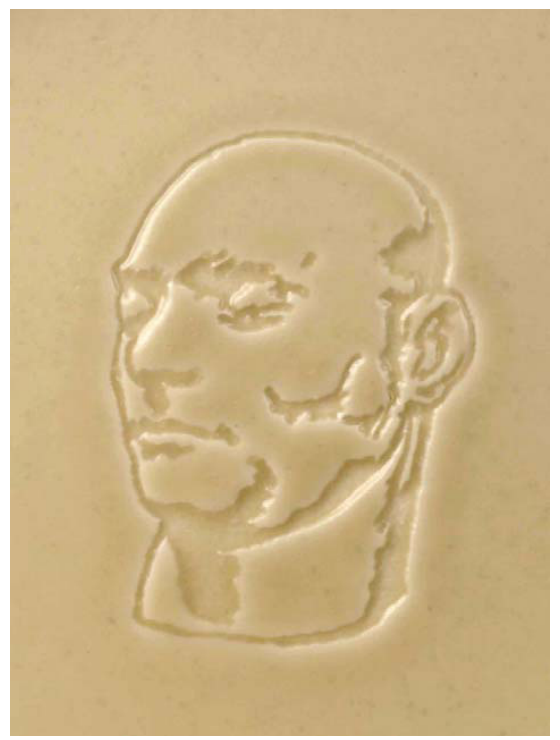

Fig. 11: Detail of 'Cargo 2'. Image taken from the death mask of Ned Kelly. 
The story is graphically depicted in a series of paintings by Sidney Nolan in the collection of the National Gallery of Australia, Canberra. There is undoubtedly a popular identification with the story, as a metaphor of the poor settler society struggling against the casual brutality of the mother country, and the inherent racism and political corruption of the colonial authorities.

The potency of the legend is reinforced by the image of Kelly's homemade suit of armour. Roughly hammered out from plough mould-boards, the armour is now widely regarded as an Australian national treasure, and is revered as such in the State Libraries of Victoria in Melbourne. The popularity of the story can also be seen as an expression of independence, the Ned Kelly story has become one of the first truly Australian post-colonial narratives.

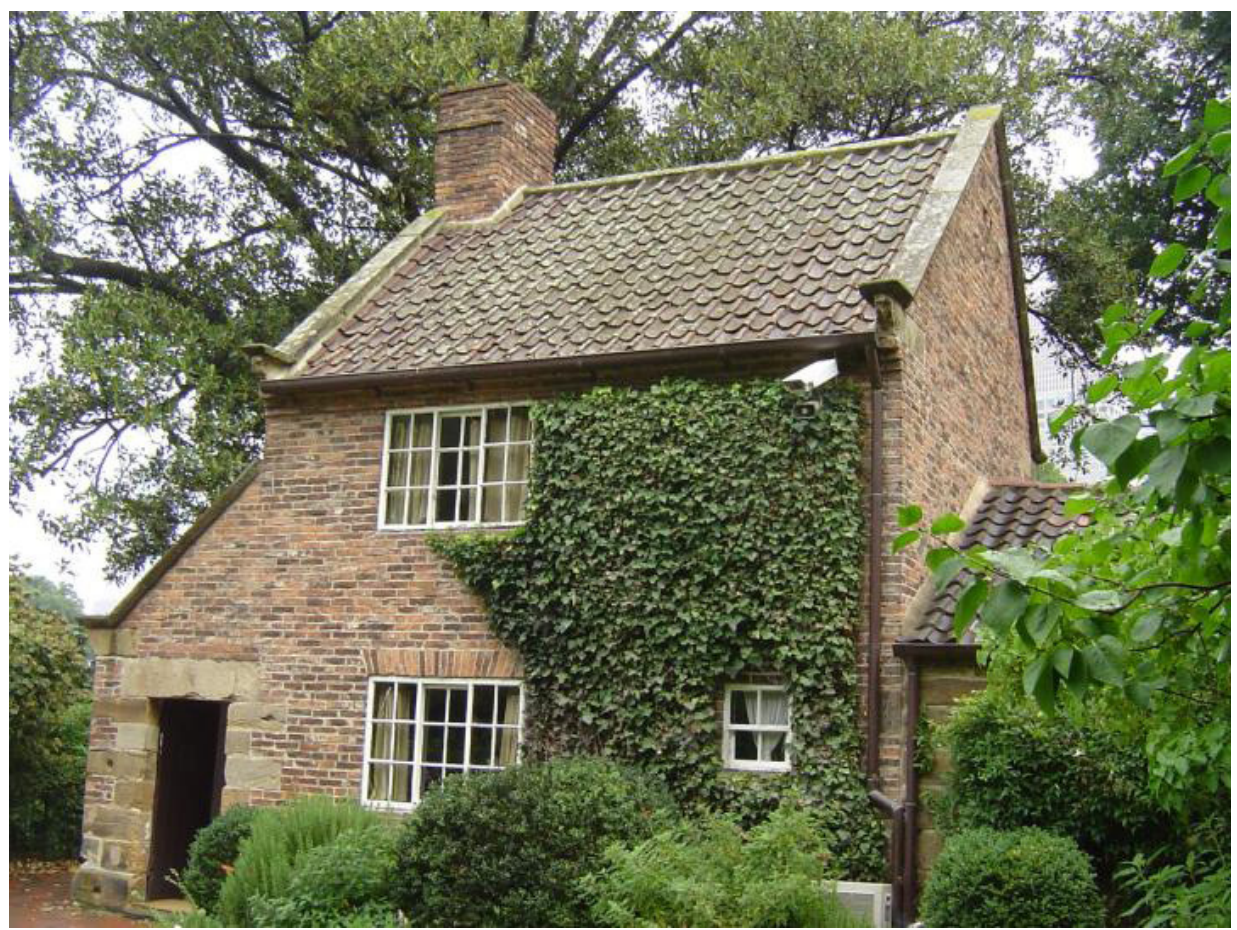

Fig. 12: 'Captain Cook’s Cottage', Fitzroy gardens, Melbourne.

I had also become interested in the inter-relationships between history, heritage and popular culture. Captain Cook's 'annexation' of New South Wales in 1770, leading to British colonisation in 1788, is celebrated by one section of Australian society, as epitomised by Cook's cottage (actually the home of his parents) being 'transported' brick by brick from Great Ayton in North Yorkshire to Fitzroy Gardens in Melbourne in 1934, to become another iconic national treasure, and arguably the 'oldest' building in Australia. (Fig. 12) Yet there is an alternative view, as many Australians regard these dates as the commemoration of '150 years of misery and degradation imposed upon the original native inhabitants by the white invaders of this country.' (Ferguson and Patten, 1938) 


\section{A New Body of Work}

The 'Beyond the Seas' research residency was completed in April 2006, but work on the project continued in the studio for the next 2 years. A number of research strands emerged in the studio, developed through models, marquettes and sampling. The inter-relationship between heritage, pop-culture and craft practice discussed earlier was explored through the house-image (the crafted house-form is a long term research interest of mine). This had developed into a model based on contemporary photographs of the Kelly family home at 11 Mile Creek, near Greta, Victoria, combining the constructional logic of 'woodcraft' models with 'making-do' materials; waxed cardboard fruit and vegetable boxes from Adelaide Central Market.

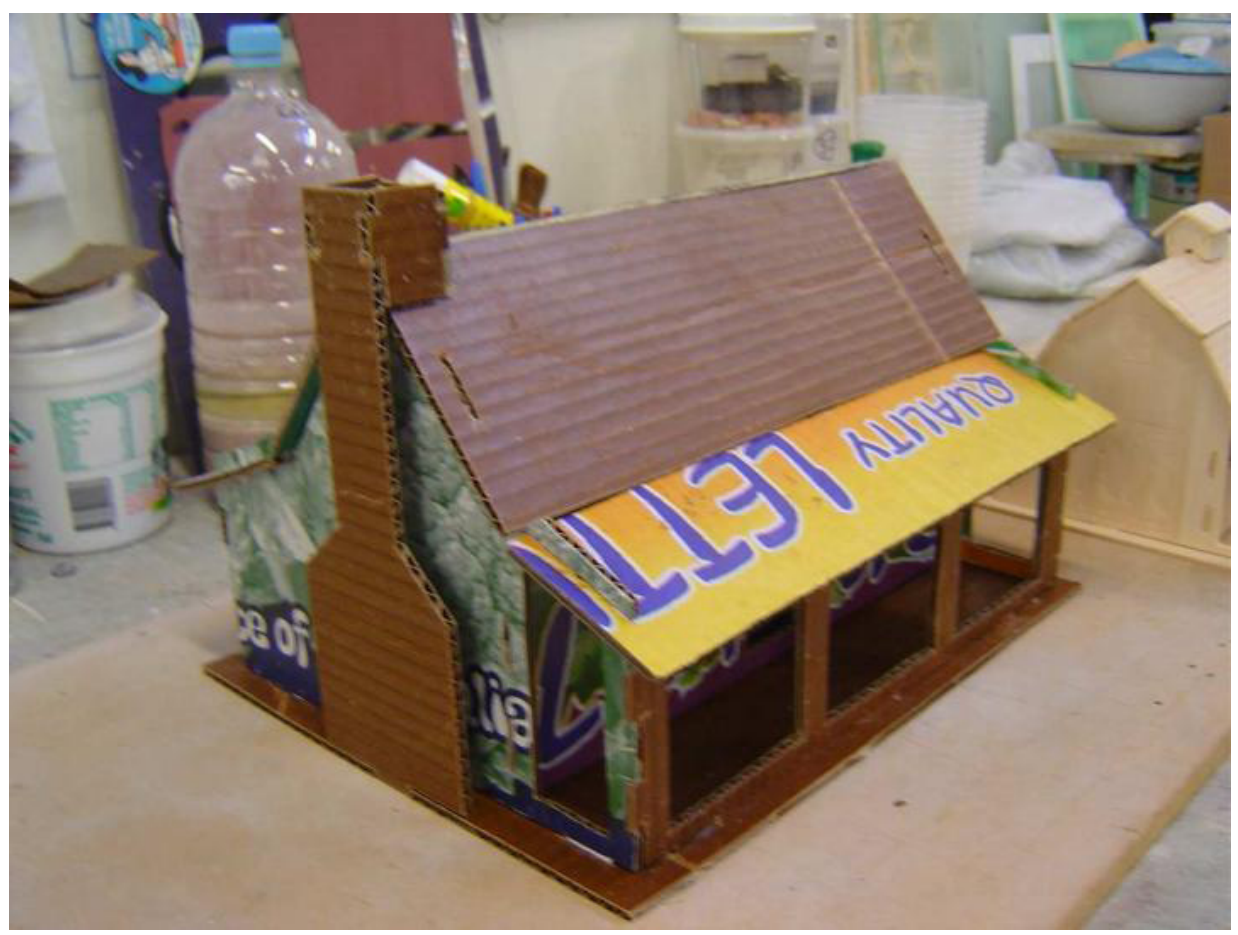

Fig. 13:. Model of Ned Kelly's family home in Greta, Victoria.

A further range of artefacts, constructed in a number of materials, explored the theme of masks, cages and outlaws. The silence hood from Melbourne Gaol was re- made and re-interpreted, and the grid-structure of prison/cage echoed in a group of hypothetical and impractical tool-forms. These pieces combine elements of making- do, by using recycled barbeque grills as source material, at the same time making reference to the contemporary Australian lifestyle. 


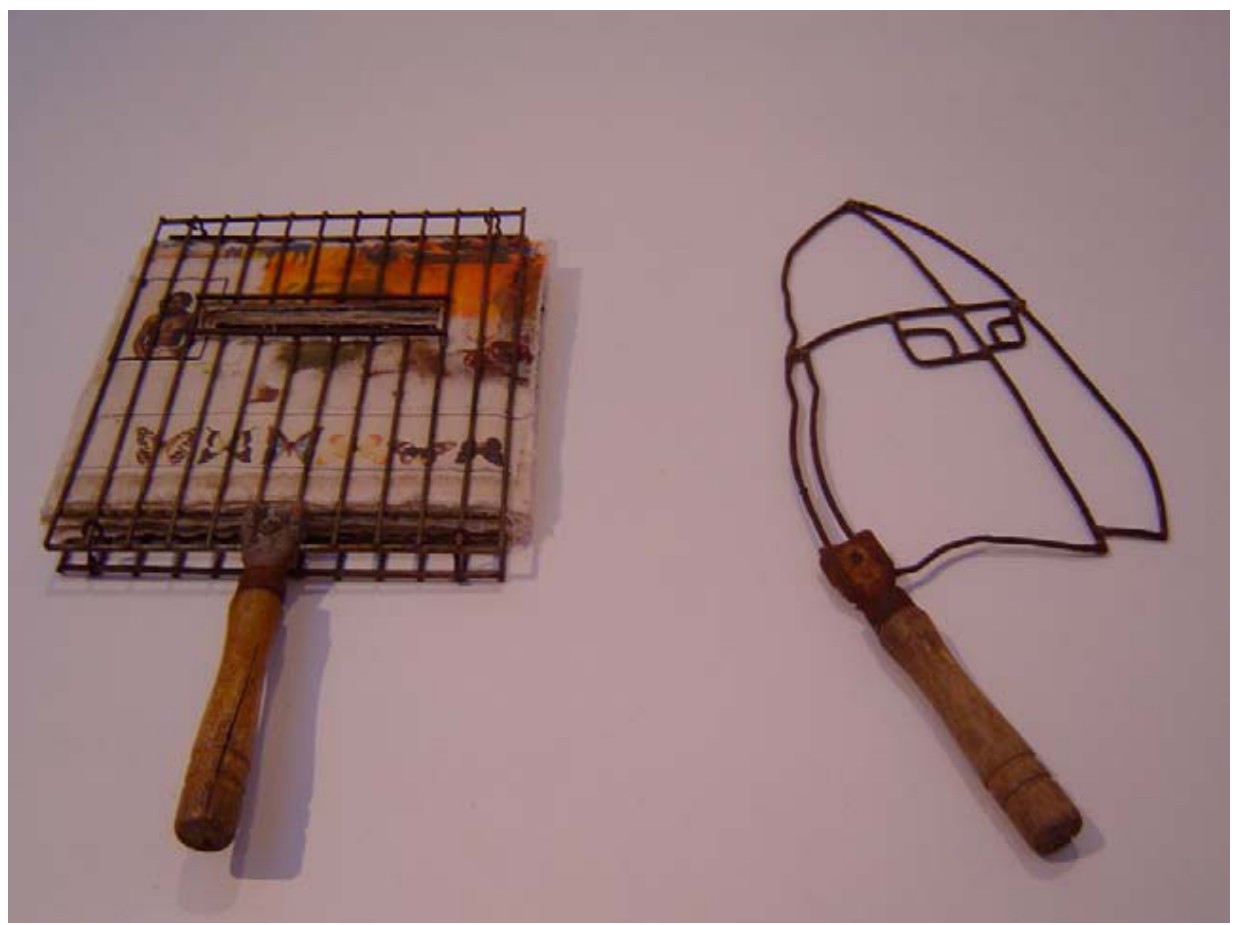

Fig. 14. 'Mask' and 'Hood'.

To support the narratives in these early pieces I constructed an 'alphabet' of iconic Australian images. An archive of line-drawings was turned into screen printed transfers, and sampled onto a variety of objects and artefacts. One of these was a series of ceramic tiles, titled 'field notes', which formed a visual diary of the project. Though they were not made 'in the field', they represent an informal note-taking, recording and experimentation consistent with the experience of fieldwork.

\section{'Cargo 1'}

Some of these images also appear on a series of plates, as an assimilation of the Australian experience into my established ceramic vocabulary. These plates are contained within a custom-made recycled steel trunk, shaped to follow the circular form of the plates, which has the superficial appearance of a colonial period hat box. The quilting of the trunk makes reference to The Sidney Nolan painting depicting Ned Kelly's sister quilting his armour. ${ }^{5}$ The textile linings are made from a collection of old and new Australian tea towels, (indicative of both domesticity and tourist souvenirs) mixed with English chintzes, the combination

5 Nolan, Sidney, 1947. Quilting the Armour a painting in the collection of the National Gallery of Australia, Canberra. 
of which state the aim of the piece to explore cross-cultural exchange. The box and its 'cargo' aim to act as metaphors for the transportation and objectification of convicts sent to Australia.

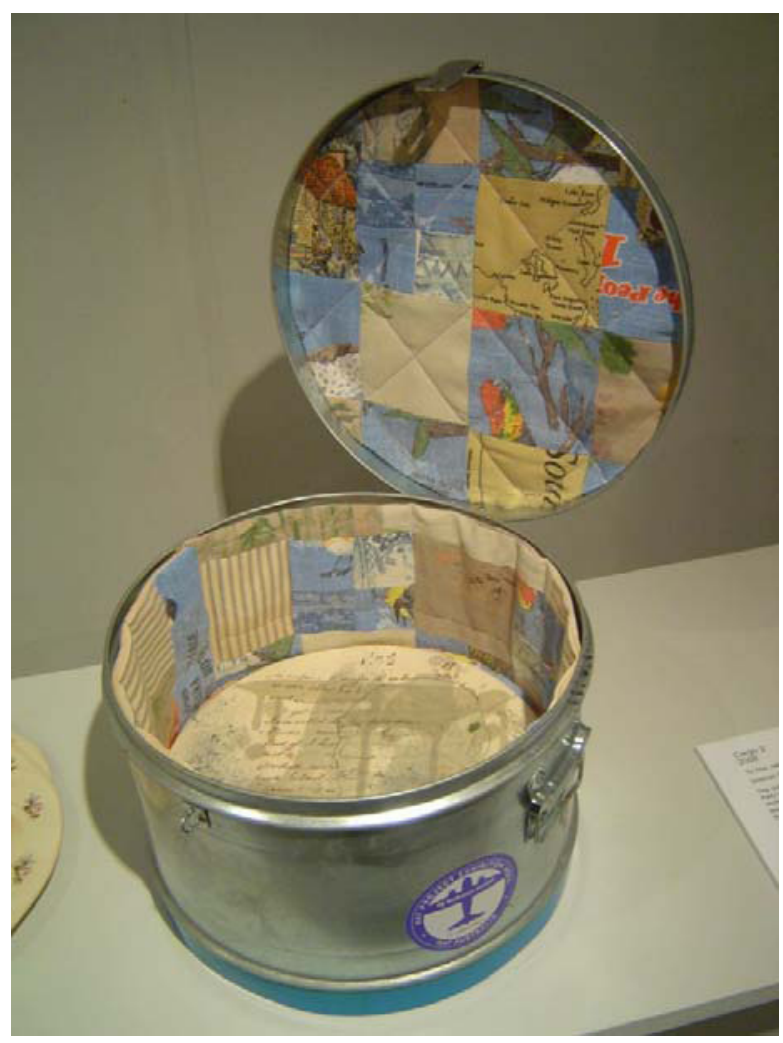

Fig. 15. Cargo 1

\section{Bush Pantry}

The making-do attitude of settlers and indigenous Australians was consciously carried into the studio, transfer printing the 'alphabet' of Australian images onto second hand enamelled tin-plates and vessels (originally collected on location in Australia) which were displayed in a 'bush pantry' made of reclaimed architectural timber. The 'staging' of the objects in this way is evocative of the need for 'making do' in a new and harsh environment, yet also signals a nostalgic pride in this past for modern Australians. 


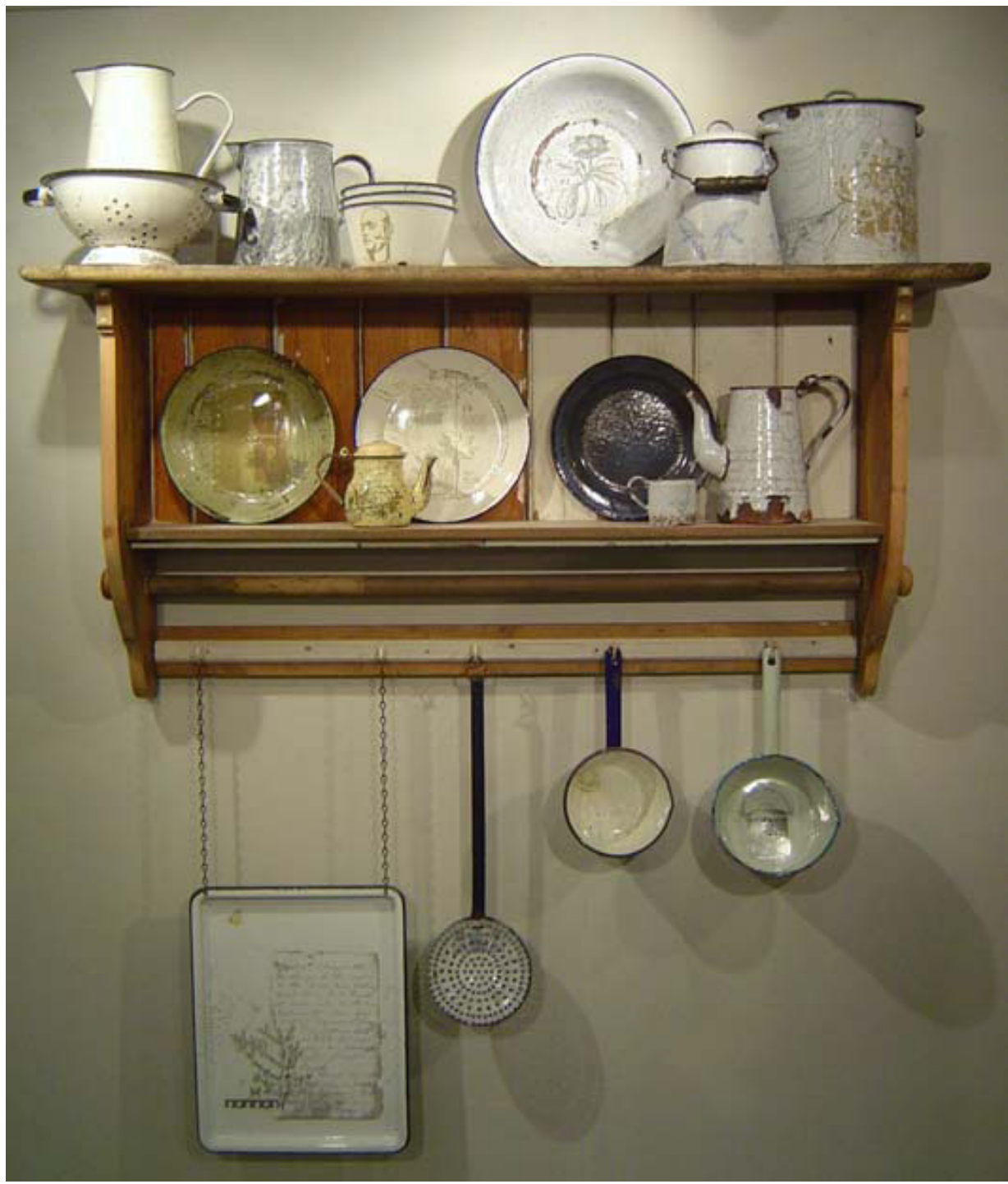

Fig. 16. Bush Pantry

The re-firing of the enamelled wares produced unpredictable surfaces, the bubbling, crazing and bloating of the enamel surface evocative of the rigours of outback living. 


\section{'Cargo 2'}

I also printed onto 'op shop'(charity shop) second-hand ceramic plates, and experimented with printing onto 'sampled' plates, which were re-cast from plaster moulds taken from colonial period originals collected in Australia. These sampled plaster moulds were also used in a piece entitled 'Cargo 2' which returned to the Kangaroo bone ash collected in Australia for both its subject matter and its material.

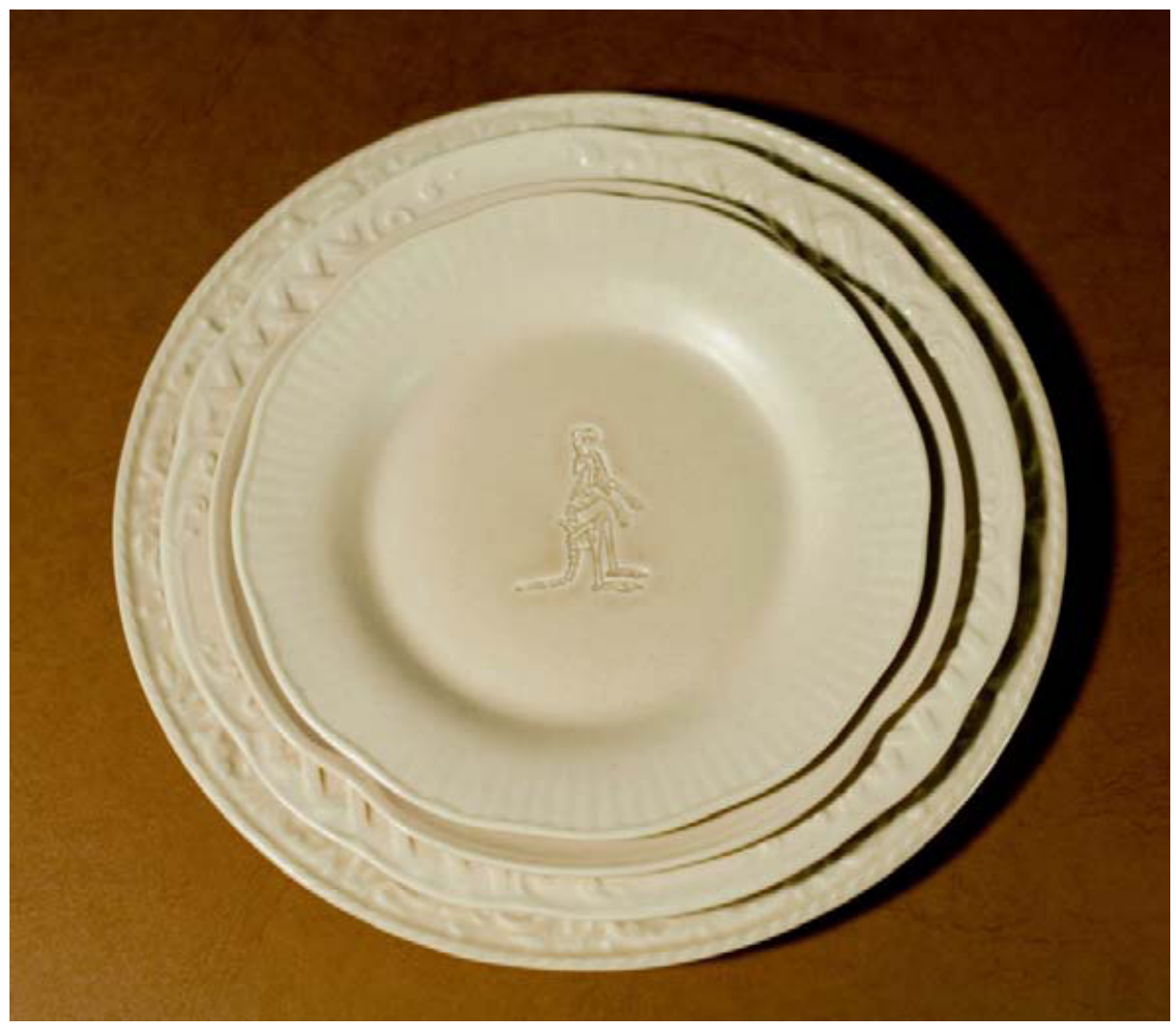

Fig. 17. 'Cargo 2' (Stacked plates).

This series of stacked plates, cast from kangaroo-bone china, was partnered with (and imprinted by) a series of stamps, made from the same china body and pewter. Pewter was selected as a material in reference to the engraved pewter plate left nailed to a tree by the Dutch navigator Dirk Hartog, the first western artefact to find its way onto Australian territory. (25 October 1616) 


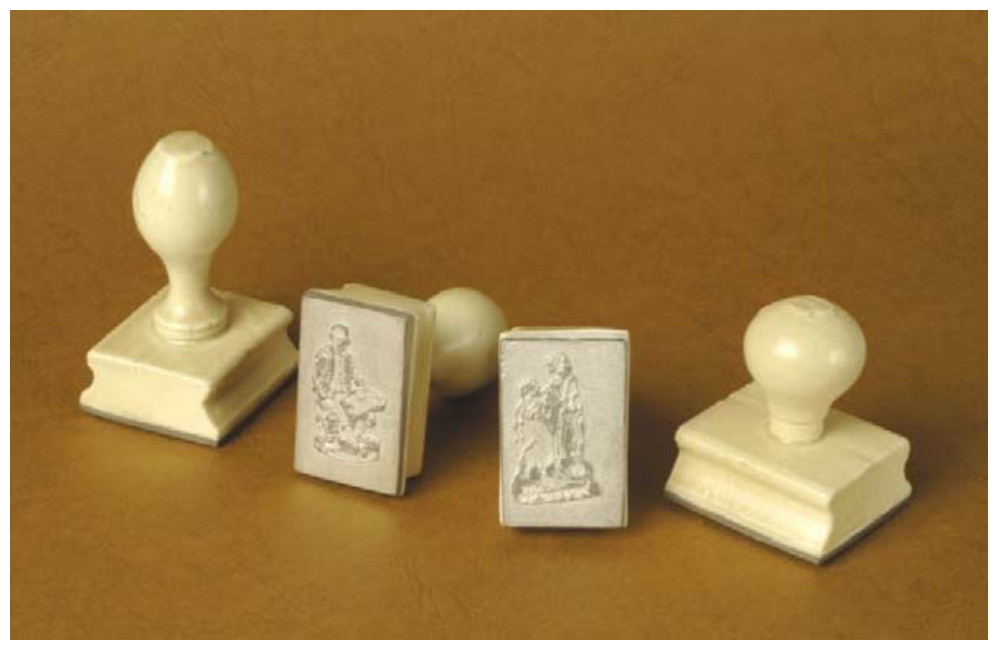

Fig. 18. Cargo 2 (Stamps).

The stamped images symbolise a distillation of my original Australian alphabet: Captain Cook; the death mask of Ned Kelly; a kangaroo skeleton; the sailor's farewell; a convict transport; Australian flora and fauna. This reductive selection of popular images represents a highly personal, invented, view of Australia, yet also documents the development of the research. The intention behind the choice of the stamp as image/object was to reference the cold and clinical bureaucracy of the colonial period and evoke the de-humanising nature of the colonial transportation policy and its associated penal regimes. In addition, the process of stamping my own images into these re-cycled/re-made plates became an act of possession, of ownership.

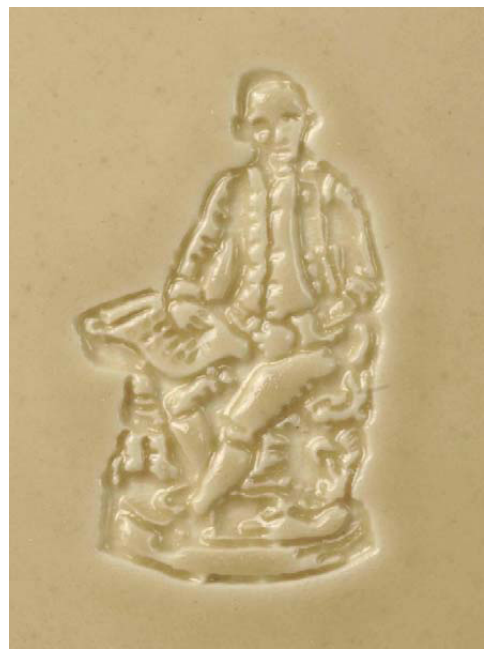

Fig. 19. Captain Cook, detail of Cargo 2. 


\section{Section 3. Conclusion.}

In the course of working through this project, I discovered what might happen to creative practice when taken out of one context and relocated to another. In the historical case of the settlers, the process of relocation resulted in the creation of unique and extraordinary artefacts (love tokens, tattoos, waggas and bush furniture) and the appropriation and adaptation of existing forms of artefact (bush toys, king plates and Kimberley points).

From a personal perspective the self-imposed 'rupture' in my creative practice was an invigorating experience, resulting in a new engagement with artefacts, materials, and narratives. The project forced me to reconsider my 'normal' practice, and gave me the freedom to explore a wider range of materials, processes and attitudes to making. The concept of 'material' as a deliberate contributor to narrative (in 'cargo 2' in particular) has been a revelation, and the most significant outcome to the development of my practice.

Since its completion the project has had several public showings:

A group of the transfer-printed enamel pieces were shown in the exhibition 'Surface Tension' at the Jam Factory in March 2006, and a selection of the collaged 'alphabet' plates was exhibited at SOFA Chicago in November 2006. A selection of work in progress was shown in Here and there: the Hat Project exhibition at the British Council in New Delhi in March 2007. Finished works were shown in 'Meeting in the Middle' at Alsager Arts Centre in February 2008 and in 'Travellers Tales' at Contemporary Applied Arts, London, in March 2009.

Two articles by Stephen Bowers, on the ceramic residencies at the Jam Factory, have been published: 'Home and Away' (Journal of Australian Ceramics) Vol 45\#2006, and 'Wandering Stars' (Ceramics: Art and Perception) no.65 2006.

The project is also extensively documented on the HAT website. (www.hat. mmu.ac.uk)

\section{Illustrations}

Figure 1 An example of re-located practice, Iron man, (enamelled tin plate). Found and re-worked on location in Adelaide, Australia, March 2006.

Figure 2: Work in progress, Jam Factory studio, March 2006.

Figure 3: Map of Australia and New Zealand, from a British geographical textbook of 1919. Figure 4: $\quad$ Detail from a map of the world (2006), painted by Indigenous artist Peter Nyaningu.

Figure 5: Detail of 'Cargo 2'. Image of a convict transport ship, from a convict love token. 
Figure 6: Adam and Eve, image taken from a convict tattoo.

Figure 7: 'Makeshifts' instruction booklet, Published by the New Settlers league of Victoria, 1923.

Figure 8: Umbarra, known as King Merriman, with king plate. Photographer William Henry Corkhill, c. 1900. National Library of Australia.

Figure 9: Racked canvasses at Freegon Art Centre, awaiting transport to galleries in the coastal cities of Australia.

Figure 10: Bones laid out for identification in the ceramic studio at the Jam Factory.

Figure 11: Detail of 'Cargo 2'. Image taken from the death mask of Ned Kelly.

Figure 12: 'Captain Cook's Cottage', Fitzroy gardens, Melbourne.

Figure 13: Model of Ned Kelly's family home in Greta, Victoria.

Figure 14: 'Mask' and 'Hood'.

Figure 15: Cargo 1

Figure 16: Bush Pantry

Figure 17: 'Cargo 2' (Stacked plates).

Figure 18: Cargo 2 (Stamps).

Figure 19: Captain Cook, detail of Cargo 2.

\section{Bibliography}

Cook, J. Journals, Vol.1. In Hughes, R., 1987. The Fatal Shore: a history of the transportation of convicts to Australia, 1787-1868. London; Sydney, Collins Harvill.

Ferguson, W. and Patten, J., 1938. From the Aborigines' Progressive Association manifesto statement. in Aboriginal Australians, First Nations of an Ancient Continent by Stephen Muecke and Adam Shoemaker, Thames and Hudson, 2004.

Field, M. \& Millett, T. eds., 1998. Convict Love tokens: the leaden hearts the convicts left behind.

Adelaide: Wakefield Press.

Harrison, R., 2006. An Artefact of Colonial Desire?: Kimberley Points and the Technologies of Enchantment. Current Anthropology, 47 (1). 
Jupp, J., 2001. The Australian People: an Encyclopedia of the Nation, its People and Their Origin.

Cambridge: Cambridge University Press.

Maxwell-Stewart, H. \& Bradley, J., 1998. Convict tattoos: Tales of freedom and coercion. In Field, M. \& Millett, T. eds., 1998. Convict Love tokens: the leaden hearts the convicts left behind. Adelaide: Wakefield Press.

Muecke, S. and Shoemaker, A., 2004. Aboriginal Australians: First Nations of an Ancient Continent.

London: Thames and Hudson.

Schofield, A. and Fahy, K., 1990. Australian Jewellery, 19th and early 20th Century. Balmain: David Ell Press.

Tindale, N., 1974. Aboriginal tribes of Australia. Canberra: University of Canberra Press.

Troy, J., 1993. King Plates: a History of Aboriginal Gorgets. Canberra: Aboriginal Studies Press. 